\title{
In vitro effects of thiamethoxam on larvae of Africanized honey bee Apis mellifera (Hymenoptera: Apidae)
}

\author{
Daiana Antonia Tavares $^{\mathrm{a}, *}$, Thaisa Cristina Roat ${ }^{\mathrm{a}}$, Stephan Malfitano Carvalho ${ }^{\mathrm{b}}$, \\ Elaine Cristina Mathias Silva-Zacarin ${ }^{c}$, Osmar Malaspina $^{\mathrm{a}}$ \\ ${ }^{a}$ Universidade Estadual Paulista, Departamento de Biologia, Rio Claro, SP, Brazil \\ ${ }^{\mathrm{b}}$ Universidade Federal de Uberlândia, Instituto de Ciências Agrárias, Uberlândia, MG, Brazil \\ ${ }^{\mathrm{C}}$ Universidade Federal de São Carlos, Departamento de Biologia, Sorocaba, SP, Brazil
}

\section{H I G H L I G H T S}

- The effects of thiamethoxam on Apis mellifera larvae were investigated.

- We determine the $\mathrm{LC}_{50}$ of thiamethoxam for larvae of Apis mellifera.

- We evaluated the effects of sublethais doses of larvae in the brain.

- Sublethal effects were observed, and discussed.

- Larval development may be altered due to exposure to thiamethoxam.

\section{A R T I C L E I N F O}

\section{Article history:}

Received 26 June 2014

Received in revised form 27 April 2015

Accepted 28 April 2015

Available online 15 May 2015

\section{Keywords:}

Neonicotinoid

Larval development

$\mathrm{LC}_{50}$

Nervous system

Sublethal effects

\begin{abstract}
A B S T R A C T
Several investigations have revealed the toxic effects that neonicotinoids can have on Apis mellifera, while few studies have evaluated the impact of these insecticides can have on the larval stage of the honeybee. From the lethal concentration $\left(\mathrm{LC}_{50}\right)$ of thiamethoxam for the larvae of the Africanized honeybee, we evaluated the sublethal effects of this insecticide on morphology of the brain. After determine the $\mathrm{LC}_{50}$ $(14.34 \mathrm{ng} / \mu \mathrm{L}$ of diet) of thiamethoxam, larvae were exposed to a sublethal concentration of thiamethoxam equivalent to $1.43 \mathrm{ng} / \mu \mathrm{L}$ by acute and subchronic exposure. Morphological and immunocytochemistry analysis of the brains of the exposed bees, showed condensed cells and early cell death in the optic lobes. Additional dose-related effects were observed on larval development. Our results show that the sublethal concentrations of thiamethoxam tested are toxic to Africanized honeybees larvae and can modulate the development and consequently could affect the maintenance and survival of the colony. These results represent the first assessment of the effects of thiamethoxam in Africanized honeybee larvae and should contribute to studies on honey bee colony decline.
\end{abstract}

(c) 2015 Elsevier Ltd. All rights reserved.

\section{Introduction}

Studies have indicated that a significant decrease in the number of Apis mellifera L. (Hymenoptera: Apidae) colonies has occurred in many countries (Stokstad, 2007; Neumann and Carreck, 2010). Multiple factors that can cause the decline of bees have been studied, including the extensive use of chemical pesticides on crops (vanEngelsdorp and Meixner, 2009). However, no consensus about this correlation has been reached (Cresswell and Thompson, 2012).

\footnotetext{
* Corresponding author at: Departamento de Biologia, Centro de Estudos de Insetos Sociais, Universidade Estadual Paulista, Avenida 24A, nํ1515, 13.506-900 Rio Claro, SP, Brazil.

E-mail address: daianazoo@yahoo.com.br (D.A. Tavares).
}

Neonicotinoids may not be directly responsible for colony losses, but they can potentially reduce the performance of honey bees and/or compromise the bees and make them more susceptible to existing pathogens or other factors that result in colony decline (Vidau et al., 2011; Pettis et al., 2013).

Sublethal effects may be characterised by physiological or behavioural alterations in surviving individuals. These responses can indicate that the functional integrity of these individuals has been affected and can contribute to a failure to perform habitual tasks (Carvalho et al., 2013). For example, studies using sublethal doses have demonstrated the toxic effects that insecticides can have on the morphology and behaviour of adult honey bees (El Hassani et al., 2007; Henry et al., 2012; Roat et al., 2013; Rossi et al., 2013a). However, our understanding of the sublethal effects of 
neonicotinoids on honeybee larvae is relatively poor compared to what has been reported for adult bees.

Neonicotinoid insecticides, which are widely used to protect various types of crops against insect pests, affect non-target insects, such as bees. These insecticides act directly by binding to the nicotinic acetylcholine receptors (nAChR) in the nervous system of insects, particularly in the neuropil regions of the brain (Tomizawa and Casida, 2003).

Studies with field doses ranging from 6 to $200 \mu \mathrm{g} / \mathrm{kg}$ have demonstrated that neonicotinoids can cause functional disturbances in the brains of honeybees, such as blocking depolarization and inhibition the nicotinic responses, and they can also cause behavioural changes that may affect the stability and survival of the colony (Palmer et al., 2013; Williamson and Wright, 2013). Additionally, exposure to neonicotinoids may result in reduced egg-laying by queens, colony growth and has been shown to result in increased mortality of Bombus terrestris. Furthermore, relevant reductions in pollen collecting efficiency by worker bees were reported (Whitehorn et al., 2012; Gill et al., 2012; Gill and Raine, 2014).

It has been established that thiamethoxam, a member of the nitro-containing neonicotinoid group, is toxic to $A$. mellifera (Iwasa et al., 2004; Badiou-Bénéteau et al., 2012). Because this insecticide is systemic, it should be considered hazardous to pollinators once the nectar, pollen and exudates can be contaminated (Girolami et al., 2009; Goulson, 2013; Godfray et al., 2014). A recent study by Henry et al. (2012) demonstrated that a sublethal dose of thiamethoxam induced homing failure in honeybees, which may affect the stability and even the survival of a colony in the field. Currently, the data available in literature regarding the toxicity of neonicotinoids to honeybee larvae are relatively poor compared to what has been reported for adult bees and bee colonies. However, research that focuses on the larval stages is important because the success of the larval phase is critical for the maintenance of a honey bee colony (Godfray et al., 2014).

Honey bee larvae require proteins and energy sources for their growth and development. These larvae rely on the proteins and carbohydrates that are contained in pollen and nectar (Babendreier et al., 2004) stored in the hive by forager workers. Studies have detected the presence of various pesticides, including thiamethoxam, in samples of pollen and nectar (Rortais et al., 2005; Chauzat et al., 2006; Mullin et al., 2010; Krupke et al., 2012) that may be used by nurse bees to feed the larvae. In addition to the pollen and nectar, the resin sources for propolis are also assumed to transfer neonicotinoids to the bee colony, including the honeycomb, and insecticides may also accumulate in these materials (Pareja et al., 2011). There are reports in the literature regarding mean or maximum field exposure rates of thiamethoxam (EFSA, 2012; Godfray et al., 2014) and modelling techniques to simulate honey bee colony dynamic for risk assessment (Henry et al., 2012; Becher et al., 2013; Bryden et al., 2013). However, doses matching in-hive exposures of larvae to pollen contaminated by insecticides have not been documented. Thus, important gaps remain in our current knowledge, especially about the possible effects that pesticides can pose to larvae of bees.

To evaluate the acute toxicity of insecticides against honey bee broods under laboratory conditions, Aupinel et al. $(2005,2007)$ proposed a specific methodology that was adopted by the OECD (2013). In field conditions, in addition to miticides, brood combs can have low concentrations of neonicotinoids, and the delayed development observed in worker broods reared in these contaminated combs (Wu et al., 2011) could be a response to the combined effect of these insecticide residues. Although the results that have been obtained for neonicotinoids under laboratory conditions do not allow for the estimation of the real effect on honey bees under field conditions, the review by Blacquière et al. (2012) states that it is important to determine the hazard of the thiamethoxam for the brood under laboratory conditions and then avoid bias in interpreting data obtained in the field.

Morphological studies can be used as tools to evaluate the toxic effects of several types of xenobiotics on cells and tissues (Malaspina and Silva-Zacarin, 2006) and these morphological approaches may be employed to examine how non-target insects, such as bees, are impacted by insecticides (Cruz et al., 2010; Gregorc and Ellis, 2011). To address the lack of data regarding the toxicity of thiamethoxam on Africanized honeybee larvae, which is necessary for the development of remedial strategies (Decourtye et al., 2013), the goal of present study was to determine in vitro the acute toxicity of thiamethoxam $\left(\mathrm{LC}_{50}\right)$, assessing the sublethal effects on morphology, larval development and using immunocytochemistry to examine the effects on the brain.

\section{Materials and methods}

\subsection{Chemicals}

The analytical standard of thiamethoxam (99.6\%) was purchased from Cluzeau Info-Labo (France). Sodium chloride $(\mathrm{NaCl})$, sodium phosphate, paraformaldehyde, glycerol, hematoxylin, and eosin were obtained from Sigma Aldrich (Brazil). The TUNEL reaction kit (ISCDDK In Situ Cell Death Detection Kit) used in the present study was obtained from Roche Molecular Biochemicals (USA). The Historesin Embedding Kit and Histosec paraffin were purchased from Leica Microsystems (Germany) and Merck (Brazil), respectively.

\subsection{Honey bee breeding and collection}

The honeybee larvae were reared in vitro using the methodology described by Aupinel et al. (2005, 2007). Larvae were obtained from healthy hives at the apiary of the Department of Biology, UNESP, Rio Claro/Brazil. To obtain first instar larvae, empty combs were placed inside a beehive for queen laying. First instar larvae (with no more than $24 \mathrm{~h}$ ) were collected and transferred to plastic queen-starter-cell. Before the larvae were transferred from the hive, plastic cells were disinfected for $30 \mathrm{~min}$ with a solution of sodium dichloroisocyanurate $0.2 \%$ and then dried in a laminar-flow hood. Afterwards, cells were arranged in a 48-well cell plate where each well was filled with a dental roll impregnated with $500 \mu \mathrm{L}$ of solution containing glycerol $15 \%$ and sodium dichloroisocyanurate $0.2 \%$ according OECD (2013). Each cell received $20 \mu \mathrm{L}$ of diet $\mathrm{A}$. Plates containing the plastic queen starter cells were kept throughout the experiment in a sealed box at $34 \pm 2{ }^{\circ} \mathrm{C}$ and a relative humidity of $90 \pm 5 \%$ in the dark.

\subsection{Diet and larval feeding}

Three types of diets (A, B, and C) containing different concentrations of nutrients were used to meet the nutritional requirements of each larval stages. These diets contained $50 \%(\mathrm{w} / \mathrm{w})$ of royal jelly and $50 \%(\mathrm{w} / \mathrm{w})$ of an aqueous solution (distilled water) with $24 \%$ sugar (D-glucose and D-fructose) and 2\% yeast extract (diet A); $30 \%$ sugar (D-glucose and D-fructose) and 3\% yeast extract (diet B); or 36\% sugar (D-glucose and D-fructose) and $4 \%$ yeast extract (diet C). On the first day of in vitro rearing, each larva was fed with $20 \mu \mathrm{L}$ of diet $\mathrm{A}$; for the third day, the larvae were fed with $20 \mu \mathrm{L}$ of diet $B$ and for the fourth, fifth and sixth days, the larvae were fed respectively with $30 \mu \mathrm{L}, 40 \mu \mathrm{L}$ and $50 \mu \mathrm{L}$, of diet C. At the 2 nd day, larvae were not fed in accordance with the methodology adopted and validated by Aupinel et al. (2005, 2007). From these 
authors, this period is necessary in order to acclimatize the larvae in laboratory conditions.

\subsection{Acute toxicity assay and larval development assessment}

We prepared a stock solution of $1000 \mathrm{ng}$ of thiamethoxam $/ \mu \mathrm{L}$ of acetone + water in the ratio 1:9. Subsequently, from the stock solution, a cascade dilution was done using as solvent the previously prepared diet C, and so obtaining seven concentrations of thiamethoxam ranged from 0.1 to $200 \mathrm{ng}$ active ingredient (a.i. $/ \mu \mathrm{L}$ ) in the diet and also control group. The larval food contaminations were done from these six solutions previously prepared on the 4th day of the bioassay, and afterwards at the 5th and 6th day, larvae received only food without the insecticide. For each concentration, 3 replicates of 12 larvae were used and larval mortality was checked after $48 \mathrm{~h}$ of exposure. The data were subject a log-normal regression (classic probit regression) using the drc package (Ritz and Streibig, 2005) and R platform ( $R$ Development, 2015). To ensure the fitness of our data analysis, a second parameterization was used to check the $\mathrm{LC}_{50}$ (log-logisti c/log-normal). From the log-logistic model fitted to the data (with three parameters), the median lethal concentration $\left(\mathrm{LC}_{50}\right)$ and the 95\% confidence interval were estimated.

Africanized honeybee development was observed and described by the categorization method of Michelette and Soares (1993). Among the larval stages of the honeybee, the fifth instar is the longest and can be divided into the following 9 periods: three periods in the feeding phase (LF1, LF2, and LF3), three periods in the spinning phase (LS1, LS2, and LS3) and three periods in the prepupal phase (PP1, PP2, and PP3). The phases were identified on the basis of larval position within the cell and the presence or absence of intestinal contents. Mortality was also checked daily, and larvae were considered dead when they were opaque in colour and immobile when stimulated by touch. The toxic effects on larvae were assessed either in the control treatment and in those treated with thiamethoxam. The results are described and those possible significant differences were denoted using the Fisher Exact Test by the R platform (R Development, 2015).

\subsection{Acute and subchronic exposure of larvae to sublethal concentration of thiamethoxam}

For the acute exposure bioassay (single exposure OECD, 2013), a food solution containing $1.43 \mathrm{ng}$ a.i./ $\mu \mathrm{L}$ of thiamethoxam in $\operatorname{diet} \mathrm{C}$, corresponding to $1 / 10$ of $\mathrm{LC}_{50}$, was prepared. On the 4 th day of the bioassay, larvae were exposed to acute treatment (with $30 \mu \mathrm{L}$ of food solution containing $1.43 \mathrm{ng}$ a.i. $/ \mu \mathrm{L}$, and on the 5 th and 6 th day they received only food without the insecticide. For subchronic bioassay (repeated oral exposure with less than $10 \%$ of dead - EPA, 2011), we use the same concentration of acute intoxication, divided into 3 consecutive days, which is equivalent to $0.47 \mathrm{ng}$ a.i $/ \mu \mathrm{L}$ per day. Larvae were daily fed on the 4 th, 5 th, and 6 th days with 30,40 and $50 \mu \mathrm{L}$ of contaminated food solution. The control group received an uncontaminated diet that consisted only of diet C. Exposure of larvae to thiamethoxam through the food was perfectly controlled. During the evaluations, larval mortality and atypical development were assessed (i.e., larval positioning and changes in the progression of larval instars). For each exposure condition, 3 replicates of 12 larvae were used.

\subsection{Histology and immunocytochemistry}

Were collected 10 larvae for each experimental group (control, acute or subchronic), 5 for the morphology analyses and 5 for immunocitochemical analyses, for the times of 24,48 and $72 \mathrm{~h}, \mathrm{a}$ total of 30 larvae for each group. These times corresponded to the following periods of the fifty instar: LF1 (initial feeding phase), LF3 (final feeding phase) and LS1 (initial spinning phase), respectively. The larvae were dissected, the anterior extremity of the body larva (head) was removed with the aid of appropriate instrumentation. Heads were immersed for $2 \mathrm{~h}$ in a solution of $100 \mathrm{mM}$ sodium phosphate buffer ( $\mathrm{pH} 7.4$ ) containing $4 \%$ paraformaldehyde. Subsequently, in accordance with the procedures of Silva-Zacarin et al. (2012), the heads (brains) were washed in $100 \mathrm{mM}$ sodium phosphate buffer $(\mathrm{pH} 7.4)$ at $4{ }^{\circ} \mathrm{C}$ and gradually dehydrated in ethanol $(15 \%, 30 \%, 50 \%, 70 \%, 85 \%, 90 \%, 95 \%$, and $100 \%)$.

For the morphological analyses, the heads were embedded in historesin, and $5 \mu \mathrm{m}$ sections were prepared using a Leica microtome and these were stained with hematoxylin-eosin (H.E). For the immunocytochemical analyses, the heads were removed from the alcohol solution and immersed in xylene and then embedded in paraplast to be sectioned into $7 \mu \mathrm{m}$ thickness sections. The In Situ Cell Death TUNEL Detection Kit was used in accordance with the manufacturer's instructions. Negative control labelling was achieved by substituting the deoxynucleotidyl transferase (TdT) enzyme with PBS. The positive control was prepared by incubating sections with DNase I $(3000 \mathrm{U} / \mathrm{ml}$ in $50 \mathrm{mM}$ Tris-HCl pH 7.5 containing $1 \mathrm{mg} / \mathrm{ml}$ bovine serum albumin) for $10 \mathrm{~min}$ at $25^{\circ} \mathrm{C}$ to induce DNA strand breaks prior to the labelling procedure. After the completion of the immunocytochemical tests, the sections were counterstained with Mayer's hematoxylin to ensure that the labelled cells had been correctly visualised.

\section{Results}

\subsection{Acute toxicity and larval development assessment}

The acute toxicity test established that the $\mathrm{LC}_{50}$ of thiamethoxam for Africanized A. mellifera larvae was $14.34 \mathrm{ng}$ a.i./ $\mu \mathrm{L}$ of diet $(48 \mathrm{~h})$ with a $95 \%$ confidence interval of $2.75-$ $25.94 \mathrm{ng}$ a.i. $/ \mu \mathrm{L}$ of $\operatorname{diet}\left(\mathrm{DF}=25\right.$ and $\chi^{2}=32.009$; Fig. 1$)$. A sublethal concentration equivalent of $1 / 10$ of $\mathrm{LC}_{50}$ of thiamethoxam was calculated as $1.43 \mathrm{ng}$ a.i./ $\mu \mathrm{L}$. During the bioassay, the mortality rate for the control group did not exceed $10 \%$, thus validating the test.

Acceleration in larval development was observed $48 \mathrm{~h}$ after the exposure with thiamethoxam and from the statistical analysis only for the concentration of $5 \mathrm{ng} / \mu \mathrm{L}$ was observed a significant difference $(p=0.01)$. However, from the Figs. 2 and 3, was observed a decrease in the time development since the lowest concentration of thiamethoxam and reaching the lower value when larvae were exposed at $5 \mathrm{ng} / \mu \mathrm{L}$. In opposite from this point, was observed an increase in the larval development time for the concentrations of $10,20,50$, or $100 \mathrm{ng} / \mu \mathrm{L}$. In overall, the development time of larvae exposed to thiamethoxam showed a biphasic pattern characterized as one hyperbola (Fig. 2). Additionally for those treatments with high concentrations of thiamethoxam $(20,50$ and $100 \mathrm{ng} / \mu \mathrm{L})$, were observed that individuals had a reduction in body size probably occasioned by the modification in the behaviour of food intake. This statement may be suggested once was found larval diet in the bottom of cells.

\subsection{Morphological analyses of the brain}

Through morphological analysis of the brain, we found that the optic lobes were most prominently affected by the insecticide. In the optic lobes from all of the samples (Fig. 4A-I), the lobula, inner chiasma, and medulla layers could be visualised. In both the acute (Fig. 4D-F) and subchronic (Fig. 4G-I) treatment groups, larvae 


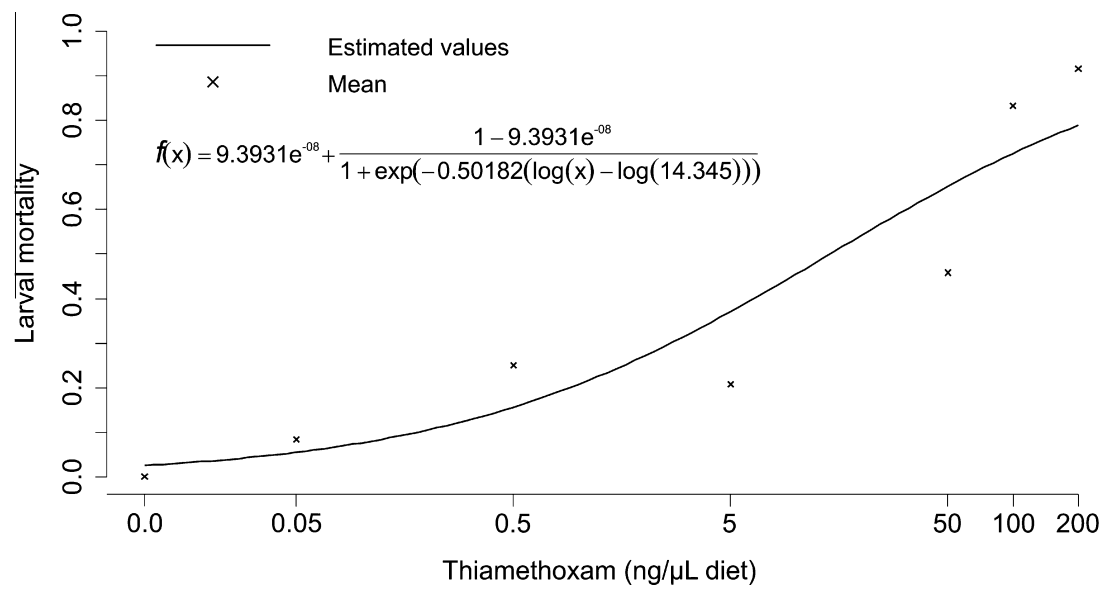

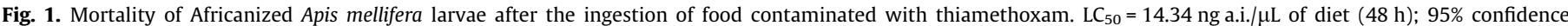

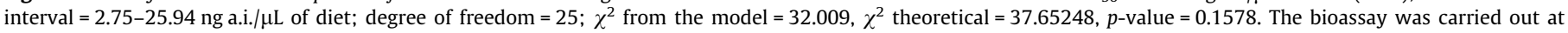
completely randomized design using seven concentrations of the insecticide divided each one in 3 replicates of 12 larvae per concentration. $n=252$ larvae.

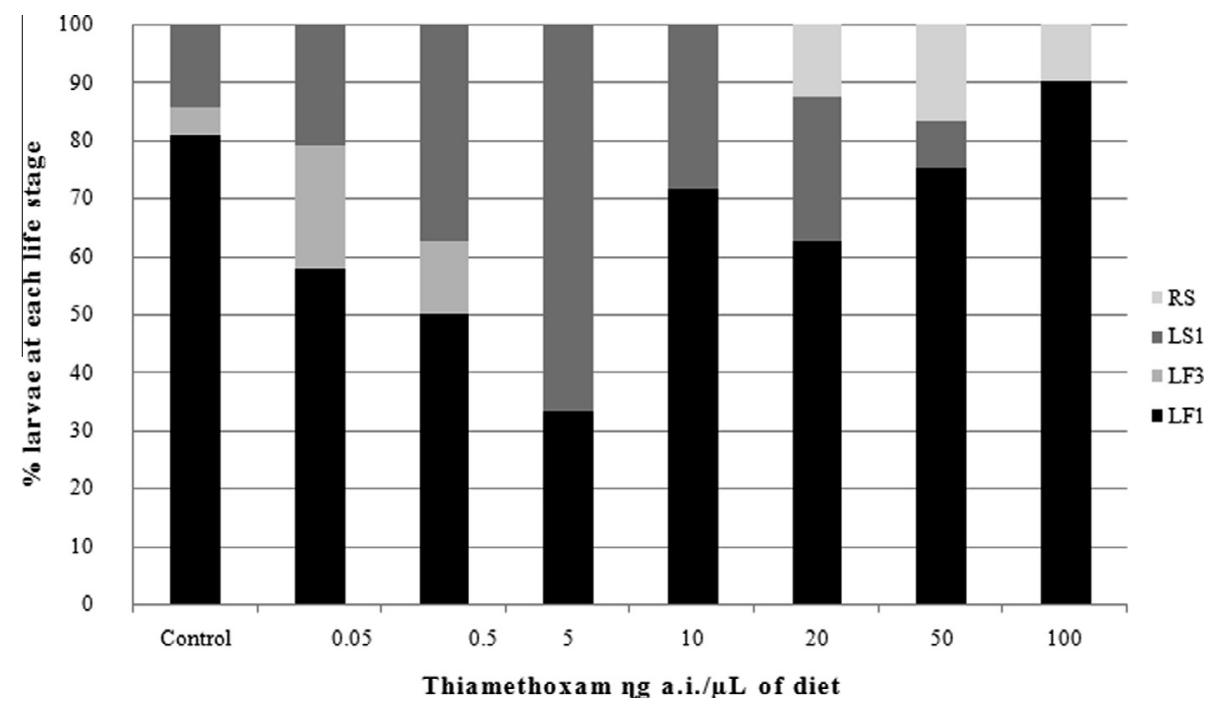

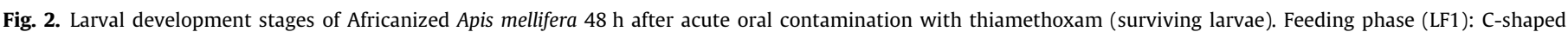

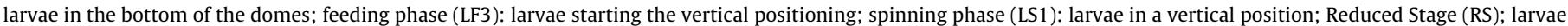

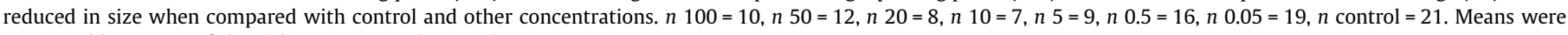
compared by means of the Fisher Exact Test $(p<0.05)$.
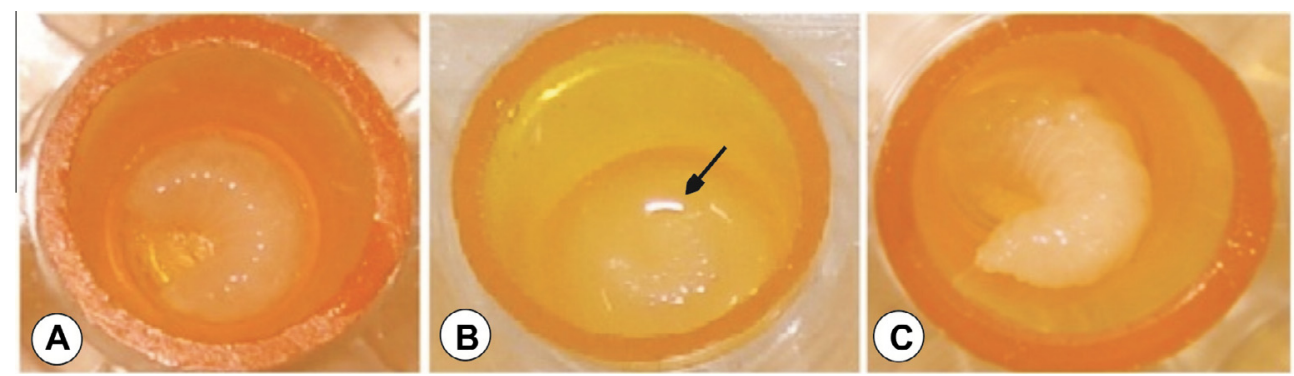

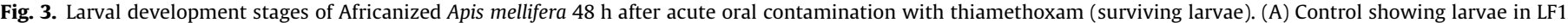

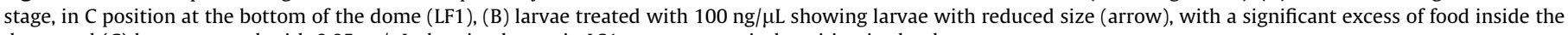
dome and (C) larvae treated with $0.05 \mathrm{ng} / \mu \mathrm{L}$ showing larvae in LS1 stage, on vertical position in the dome.

from the initial subphase of the 5th instar (LF1) exhibited intensely stained cells in the medulla layer, indicating cellular condensation, characteristic of cells in the process of death. For the control group (Fig. $4 \mathrm{~A}-\mathrm{C}$ ), strongly stained cells were found only after the LF3 subphase.
No morphological changes due to thiamethoxam treatment were observed in the other analysed brain structures (namely, mushroom bodies and antennal lobes). The differentiation of the mushroom bodies, as evidenced by the presence of large quantities of neuroblasts and Kenyon cells and the initiation of differentiation 

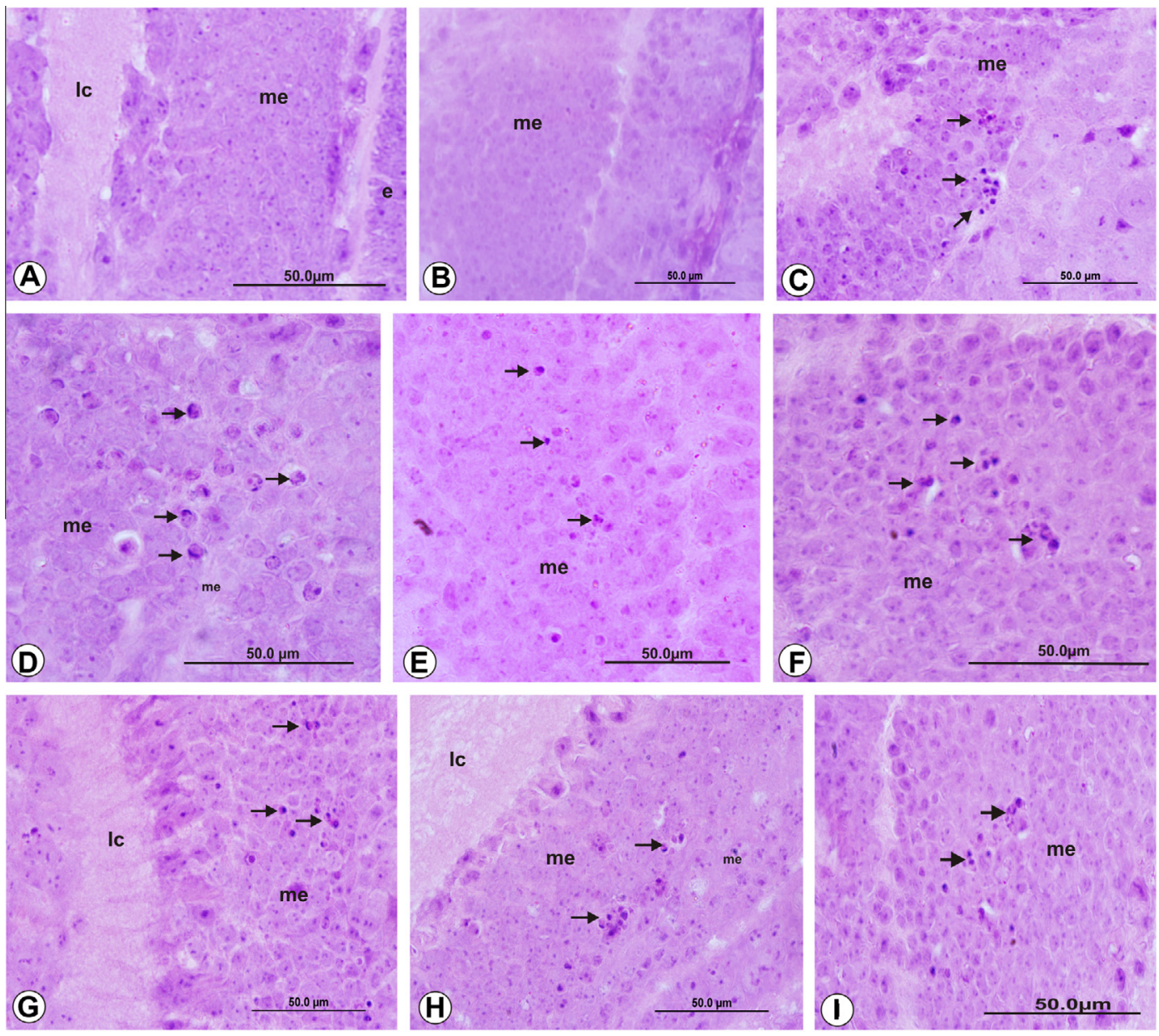

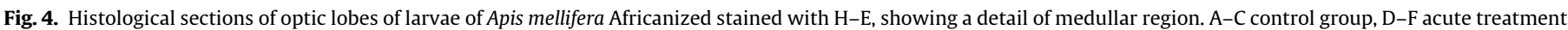

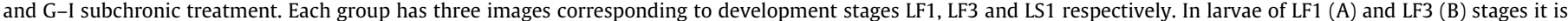

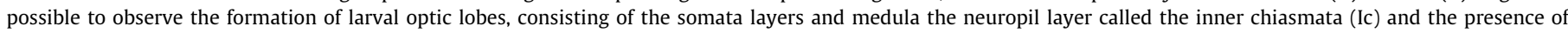

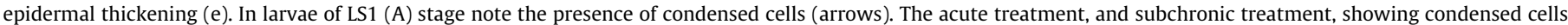
(arrows) in all stages analysed D-I.

in the peduncles of these bodies, was observed during all subphases of the 5th instar stage (Fig. 5A-I) in not only the control group (Fig. $5 \mathrm{~A}-\mathrm{C}$ ) but also the groups that received acute (Fig. 5D-F) or subchronic (Fig. 5G-I) thiamethoxam treatment. It was also possible to observe the initiation of the formation of the antennal lobe, as evidenced by the development of a central neuropil region and the presence of peripheral neurons other than glial cells; this process was first noted in the LF3 subphase for the control group (Fig. 6A and B) and for the group that received the acute treatment (Fig. 6C and D), but it was observed in all subphases of the 5th instar stage for the group that received the subchronic treatment (Fig. 6D and F).

\subsection{In situ cell death detection kit - TUNEL}

Nuclei that were positive in the TUNEL assay were observed in the medulla layer of the optic lobes, indicating that the cells that were most strongly stained during the morphological analyses of all groups and exposure conditions were undergoing cell death process (Fig. 7). Moreover, we noted that in the optic lobes, the cell death processes begin earlier in the groups that received acute or subchronic thiamethoxam treatment than in the control group.

\section{Discussion}

Here, we stablish the oral $\mathrm{LC}_{50}$ of thiamethoxam for the larvae of Africanized honeybees in the laboratory conditions being also the first report available in scientific literature. Comparing our result of $\mathrm{LC}_{50}$ for larvae with those for adult of Africanized A. mellifera (4.28 ng a.i./ $\mu \mathrm{L}$ of diet - Oliveira et al., 2013), we observe that larvae seems to be more tolerant to thiamethoxam rather than adults. In accordance with our study, this hypothesis was also suggested by Yang et al. (2012) which observed that larvae were more tolerant to the imidacloprid when were compared with adult of $A$. mellifera. However and even with the discrepancy in the sensitivity of the honeybee during its development, these authors highlight that the toxic effect of this insecticide at low doses may be harmful and affect the larvae. To illustrate this statement, we found with this study that sublethal doses of thiamethoxam can cause atypical progression of developmental stages, and the development of the optic lobes larvae. Additionally, changes in larval development can be the major threat for honeybee colonies, and these effects should be considered, for a complete analysis of pesticides (Desneux et al., 2007; Thompson, 2003) and still have a lack of information about this subject in the literature (Arena and Sgolastra, 2014). 

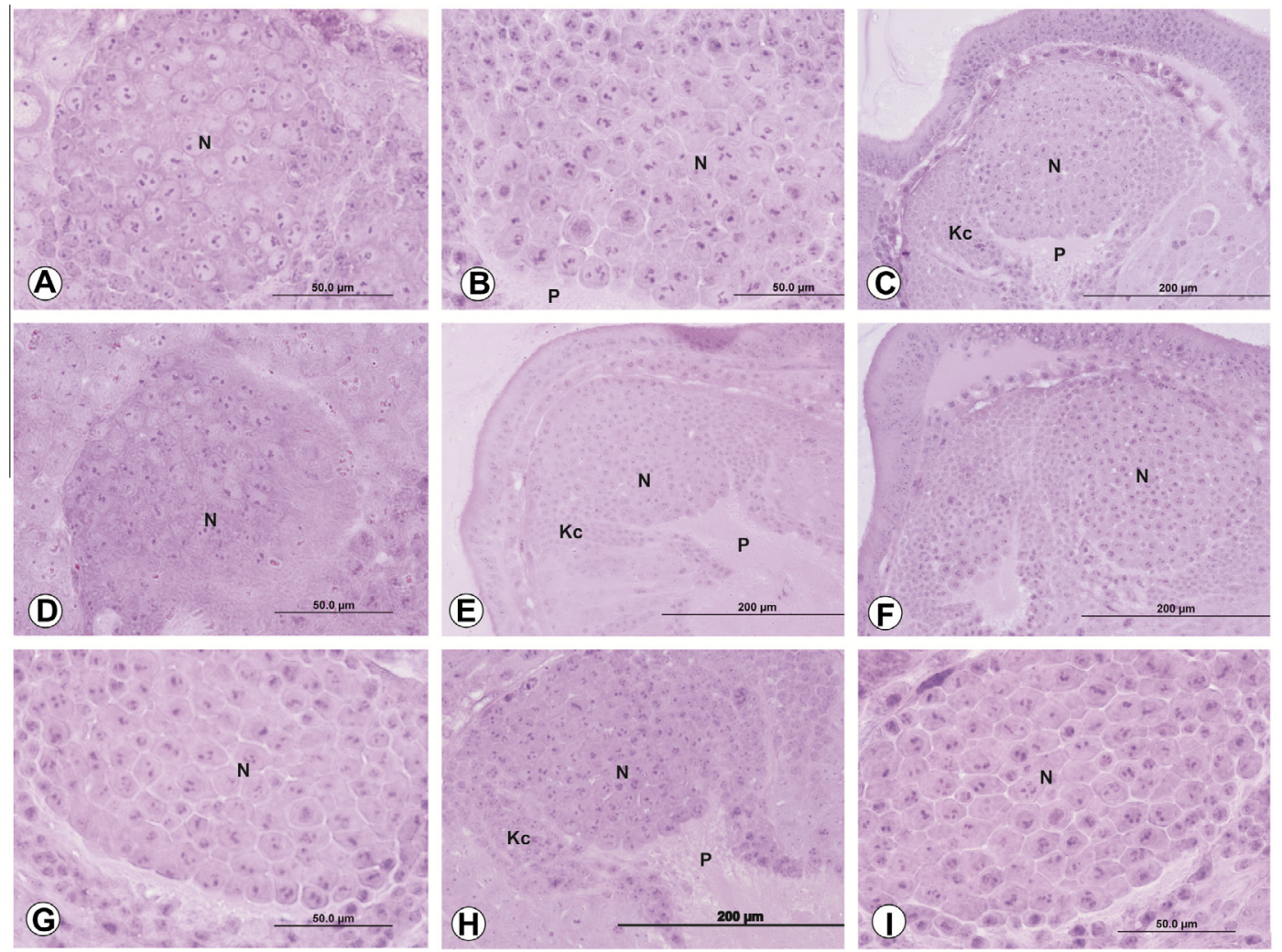

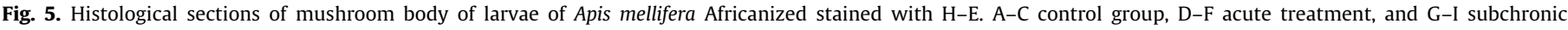

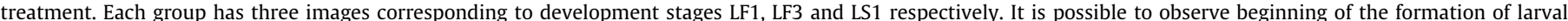

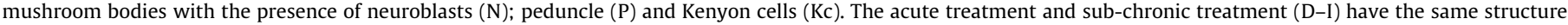
and morphology of mushroom bodies from control group.

Studies that evaluated the effects of insecticides on A. mellifera larval development concluded that these substances can alter normal patterns of development. Davis et al. (1988) found that the growth of $A$. mellifera larvae exposed to dimethoate $(0.313$ a.i. $\mu \mathrm{g} / \mathrm{g}$ royal jelly) was stimulated in comparison with non-treated larvae. The same study, found that certain larvae treated with the insecticide lost their typical C-shape and were either dorsally or dorsolaterally elongated and, moreover, the number of larvae that failed to spin cocoons was greater in the treated larvae groups. According to Davis et al. (1988) this type of behaviour may be related to changes in the levels of juvenile hormone and ecdysone in response to the intoxication with the pesticide.

Although the residues of thiamethoxam found in the field are below of the concentration that we used to intoxicate the larvae, our results demonstrate the hazardous effects of thiamethoxam during larval development of Africanized honeybee. We highlighted the relevance of determining the hazard of the thiametoxam for the honeybee brood, once once thiamethoxam was recently detected in bee bread (Giroud et al., 2013). In addition, Yang et al. (2012) did not exclude the possibility of cumulative intoxication through the repetitive consumption of honey and pollen contaminated with residues of the neonicotinoids. Little is known about the effects of thiamethoxam on honeybee larvae although, some studies on the toxicity of dimethoate, fenoxycarb, (Aupinel et al., 2007) fipronil and boric acid (Cruz et al., 2010) have been conducted and showed that these compounds are toxic to larvae. For this reason, Blacquière et al. (2012) emphasised that studies regarding the effects of neonicotinoids on larvae must be conducted because the success of colonies depends on the larvae.

Morphological studies to assess the effects of insecticides in target and non-target organs have been used as a parameter to predict the risks that these compounds may pose (Malaspina and
Silva-Zacarin, 2006; Cruz et al., 2010; Roat et al., 2013; Oliveira et al., 2013). In the present study, the optic lobes of Africanized honeybee larvae exposed to a sublethal concentration of thiamethoxam exhibited alterations that were evidenced by immunocytochemical and morphological techniques, and TUNEL reactions confirmed that condensed cells were undergoing cell death process.

Under natural conditions, the larval brain undergoes a transformation during metamorphosis to fulfil the changing needs of the adult (Chapman, 1998). In an investigation of the different development patterns in the optic lobes of $A$. mellifera workers, queens and drones, Roat and Cruz-Landim (2010) used morphological and immunocytochemical approaches to demonstrate that cell death process in the optic lobes began to occur during the white-eyed pupal stage, a time point that occurs after the onset of the optic lobe cell death process that was observed in the present study. A comparison of the data from this previous study and the current investigation reveals that the exposure of $A$. mellifera larvae to sublethal concentration of thiamethoxam appeared to accelerate cell death processes in the region of the optic lobes. As Roat and Cruz-Landim (2010) did not specify the subphase of the 5th instar during their sample collection, our findings showing cell death process in the control larvae at the LS1 subphase may not be inconsistent with the results of these other authors. Instead, the cell death observed during the LS1 subphase may simply represent the beginning of normal brain remodelling processes.

However, because the optic lobes are associated with vision and orientation, the premature cell death observed in the present study, could lead to a reduction in the number of neurons in the optic lobes and if during metamorphosis the quantity of neuron is not re-established it can exacerbate the disorientation of adult bees, a phenomenon that has been discussed by vanEngelsdorp 

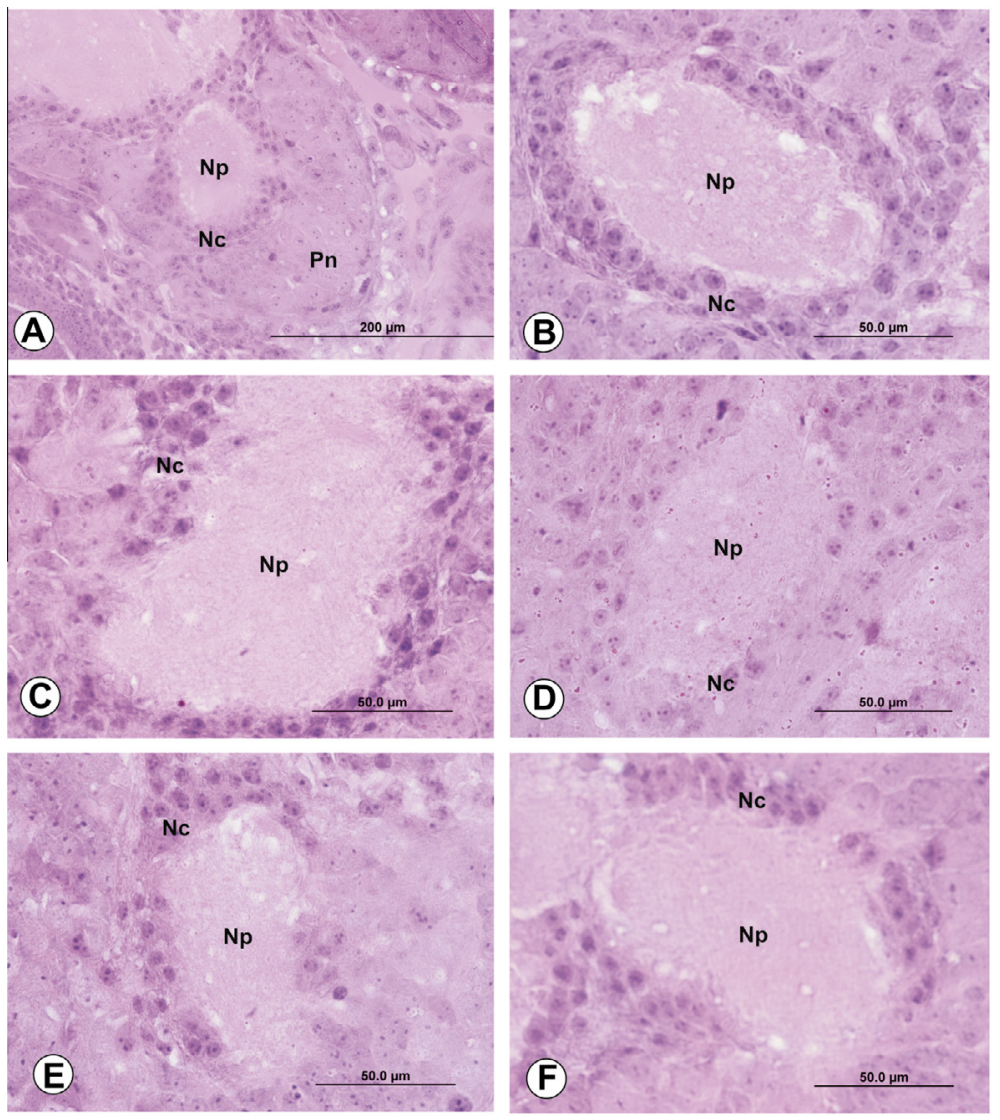

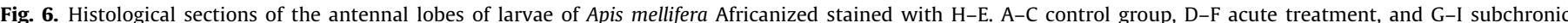

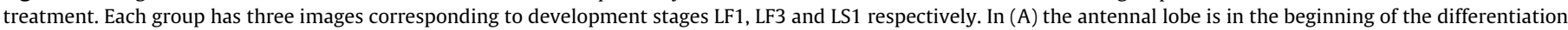

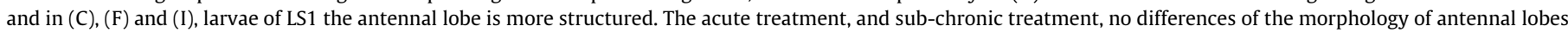
are observed. (Np) neuropil; (Nc) neuroglial cells; (Pn) peripheral neurons.
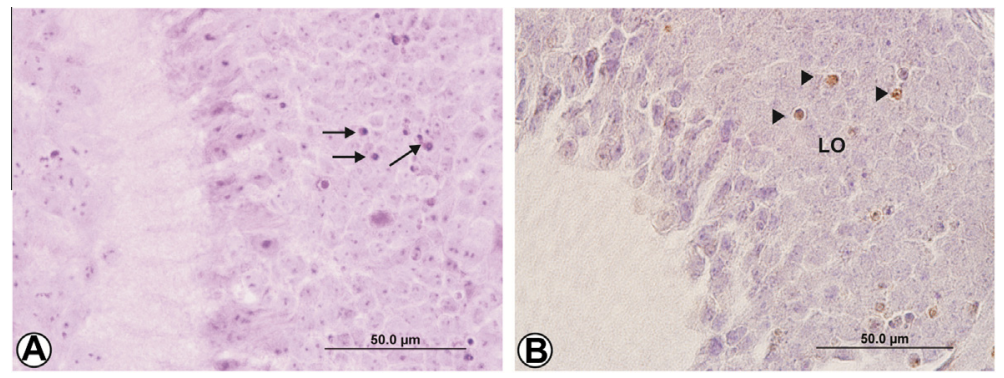

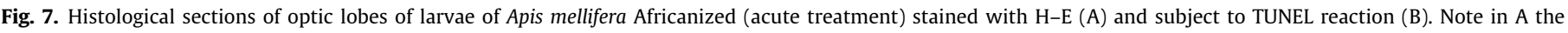
presence of condensed cells (arrow) and in B positive nuclei (head arrow) confirming the presence of cell death process.

and Meixner (2009) and Roat et al. (2013). The effects observed in the optic lobes may be due to direct toxicity of thiamethoxam, or this effect may result from the changes observed in the larval development. After this period, it may be that development is affected at later stages, or have a change with respect to development time.

In our study, we did not observe any morphological changes in the mushroom bodies or antennal lobes of larvae exposed to thiamethoxam. However, the study by Oliveira et al. (2013) with newly emerged bees exposed to thiamethoxam and those of Rossi et al. (2013b) using imidacloprid to intoxicate adults of Africanized honeybee, showed that these neonicotinoids are responsible for inducing morphological changes in the mushroom bodies and optic lobes beyond cell death.

The differences between these studies and ours can be explained in part by the population of $A$. mellifera used, the age of honeybees, and the duration and dose of exposure. Here, the optic lobes were the most developed structures, early in the 5th instar. The larval nervous system undergoes morphological changes during the metamorphosis, and their neural circuits are transformed to control complex activities in worker bees (Roat and Cruz-Landim, 2010). Considering the complex transformation procedure in the brain of larvae, may be differences in susceptibility and action compared with worker bees.

\section{Conclusion}

In conclusion, the results that have been presented in this study provide the first determination of the $\mathrm{LC}_{50}$ of thiamethoxam for larvae of Africanized honeybees, and using morphological and immunocytochemical approaches, we found important alterations in the optic lobes of the larvae that were exposed to this insecticide and that thiamethoxam can affect the larval development of $A$. 
mellifera. Thus, given that the survival of honeybee colonies depends on successful larval development, these observations may be useful for understanding the abnormal decline of A. mellifera worldwide. Furthermore, this study provides important information that should contribute to policies regarding insecticide registration purposes by regulatory agencies.

\section{Acknowledgments}

We thank the São Paulo Research Foundation (FAPESP) (grants 2009/06701-5, grants 2013/09419-4 and Thematic Project grants 2012/50197-2) and also the Instituto de Biociências from the Universidade Estadual Paulista, Rio Claro/SP, Brasil to provide the facilities during the development of the study.

\section{References}

Arena, M., Sgolastra, F., 2014. A meta-analysis comparing the sensitivity of bees to pesticides. Ecotoxicology 23, 324-334.

Aupinel, P., Fortini, D., Dufour, H., Tasei, J.N., Michaud, B., Odoux, J.F., Pham-Delègue, M.H., 2005. Improvement of artificial feeding in a standard in vitro method for rearing Apis mellifera larvae. Bull. Insectol. 58, 107-111.

Aupinel, P., Fortini, D., Michaud, B., Marolleau, F., Tasei, J.N., Odoux, J.F., 2007. Toxicity of dimethoate and fenoxycarb to honey bee brood (Apis mellifera), using a new in vitro standardized feeding method. Pest. Manag. Sci. 63, 1090-1094.

Babendreier, D., Kalberer, N., Romeis, A., Fluri, P., Bigler, F., 2004. Pollen consumption in honey bee larvae: a step forward in the risk assessment of transgenic plants. Apidologie 35, 293-300.

Badiou-Bénéteau, A., Carvalho, S.M., Brunet, J.L., Carvalho, G.A., Buleté, A., Giroud, B. Belzunces, L.P., 2012. Development of biomarkers of exposure to xenobiotics in the honeybee Apis mellifera: application to the systemic insecticide thiamethoxam. Ecotoxicol. Environ. Saf. 28, 22-31.

Becher, M.A., Osborne, J.L., Thorbeck, P., Kennedy, P.J., Grimm, V., 2013. Towards a systems approach for understanding honeybee decline: a stocktaking and synthesis of existing models. J. Appl. Ecol. 50, 868-880.

Blacquière, T., Smagghe, G., van Gestel, A.M., Mommaerts, V., 2012. Neonicotinoids in bees: a review on concentrations, side-effects and risk assessment. Ecotoxicology 21. 973-972.

Bryden, J., Gill, R.J., Mitton, A., Raine, N.E., Jansen, V.A.A., 2013. Chronic sublethal stress causes bee colony failure. Ecol. Lett. 16, 1463-1469.

Carvalho, S.M., Belzunces, L.P., Carvalho, G.A., Brunet, J-L., Badiou-Beneteau, A. 2013. Enzymatic biomarkers as tools to assess environmental quality: a case study of exposure of the honey bee Apis mellifera to insecticides. Environ. Toxicol. Chem. 32, 2117-2124.

Chapman, R.F., 1998. The Insects: Structure and Function. Cambridge University Press, New York.

Chauzat, M.-P., Faucon, J.P., Martel, A.C., Lachaize, J., Cougoule, N., Aubert, M., 2006 A survey of pesticide residues in pollen loads by honeybees in France. J. Econ. Entomol. 99, 253-262.

Cresswell, J.E., Thompson, H., 2012. Comment on “a common pesticide decreases foraging success and survival in honey bees". Science 337, 1453.

Cruz, A.S., Silva-Zacarin, E.C.M., Bueno, O.C., Malaspina, O., 2010. Morphological alterations induced by boric acid and fipronil in the midgut of worker honeybee (Apis mellifera) larvae. Cell. Biol. Toxicol. 26, 165-176.

Davis, A.R., Solomon, K.R., Shuel, R.W., 1988. Laboratory studies of honeybee larval growth and development as affected by systemic insectidides at adult sublethal levels. J. Apic. Res. 27, 146-161.

Decourtye, A., Henry, M., Desneux, N., 2013. Environment: overhaul pesticide testing on bees. Nature 497, 188.

Desneux, N., Decourtye, A., Delpuech, J.M., 2007. The sublethal effects of pesticides on beneficial arthropods. Annu. Rev. Entomol. 52, 81-106.

EFSA, 2012. Statement on the Findings in Recent Studies Investigating Sub-Lethal Effects in Bees of Some Neonicotinoids in Consideration of the Uses Currently Authorised in Europe. EFSA, Parma, p. 27.

El Hassani, A.K., Dacher, M., Gary, V., Lambin, M., Gauthier, M., Armengaud, C., 2007. Effects of sublethal doses of acetamiprid and thiamethoxam on the behavior of the honeybee (Apis mellifera). Arch. Environ. Contam. Toxicol. 54, 653-661.

EPA, 2011. Exposure Factors Handbook. US Environmental Protect Agency, Washington.

Gill, R.J., Ramos-Rodriguez, O., Raine, N., 2012. Combined pesticide exposure severely affects individual- and colony-level traits in bees. Nature 491, $105-$ 108.

Gill, R.J., Raine, N.E., 2014. Chronic impairment of bumblebee natural foraging behaviour induced by sublethal pesticide exposure. Funct. Ecol. 28, 1459-1471.

Girolami, V., Mazzon, L., Squartini, A., Mori, N., Marzaro, M., Di Bernardo, A., Greatti, M., Giorio, C. Tapparo, A., 2009. Translocation of neonicotinoid insecticides from coated seeds to seedling guttation drops: a novel way of intoxication for bees. J. Econ. Entomol. 102, 1808-1815.
Giroud, B., Vauchez, A., Vulliet, E., Wiest, L., Buleté, A., 2013. Trace level determination of pyrethroid and neonicotinoid insecticides in beebread using acetonitrile-based extraction followed by analysis with ultra-high-performance liquid chromatography-tandem mass spectrometry. J. Chromatogr. A 1316, $53-$ 61.

Godfray, H.C.J., Blacquiere, T.L., Field, M., Hails, R.S., Petrokofsky, G., Potts, S.G., Raine, N.E., Vanbergen, A.J., McLean, A.R., 2014. A restatement of the natural science evidence base concerning neonicotinoid insecticides and insect pollinators. Proc. Biol. Sci. 281, 1786.

Goulson, D., 2013. An overview of the environmental risks posed by neonicotinoid insecticides. J. Appl. Ecol. 50, 977-987.

Gregorc, A., Ellis, J.D., 2011. Cell death localization in situ in laboratory reared honey bee Apis mellifera L. larvae treated with pesticides. Pest. Biochem. Physiol. 99, 200-207.

Henry, M., Béguin, M., Requier, F., Rollin, O., Odoux, J.F., Aupinel, P., Aptel, J., Tchamitchian, S., Decourtye, A., 2012. A common pesticide decreases foraging success and survival in honey bees. Science 336, 348-350.

Iwasa, T., Motoyama, N., Ambrose, J.T., Roe, M.R., 2004. Mechanism for the differential toxicity of neonicotinoid insecticides in the honey bee, Apis mellifera. Crop. Protect. 23, 371-378.

Krupke, C.H., Hunt, G.J., Eitzer, B.D., Andino, G., Given, K., 2012. Multiple routes of pesticide exposure for honey bees. Plos One 7, e29268.

Malaspina, O., Silva-Zacarin, E.C.M., 2006. Cell markers for ecotoxicological studies in target organs of bees. Braz. J. Morphol. Sci. 23, 129-136.

Michelette, E.R.F., Soares, A.E.E., 1993. Characterization of preimaginal developmental stages in Africanized honey bee workers (Apis mellifera L.). Apidologie 24, 431-440.

Neumann, P., Carreck, N.L., 2010. Honey bee colony losses. J. Apic. Res. 49, 1-6.

Mullin, C.A., Frazier, M., Frazier, J.L., Ashcraft, S., Simons, R., van Engelsdorp, D., Pettis, J.S., 2010. High levels of miticides and agrochemicals in North American apiaries: implications for honey bee health. PLoS One 5, e9754.

OECD, 2013. Guidelines for the Testing of Chemicals, Honey bee (Apis mellifera) Larval Toxicity Test, Single Exposure No. 237.

Oliveira, R.A., Roat, T.C., Carvalho, S.M., Malaspina, O., 2013. Side-effects of thiamethoxam on the brain and midgut of the Africanized honeybee Apis mellifera (Hymenopptera: Apidae). Environ. Toxicol. 29, 1122-1133.

Palmer, M.J., Moffat, C., Saranzewa, N., Harvey, J., Wright, G.A., Connolly, C.N., 2013. Cholinergic pesticides cause mushroom body neural inactivation in honeybees. Nature 4, 1634.

Pareja, L., Colazzo, M., Pérez-Parada, A., Niell, S., Carrasco-Letelier, L., Besil, N., Cesio, M.V., Heinzen, H., 2011. Detection of pesticides in active and depopulated beehives in Uruguay. Int. J. Environ. Res. Public. Health. 8, 3844-3858.

Pettis, J.S., Lichtenberg, E.M., Andree, M., Stitzinger, J., Rose, R., van Engelsdorp, D., 2013. Crop pollination exposes honey bees to pesticides which alters their susceptibility to the gut pathogen Nosema ceranae. Plos One 98, e70182.

R Development Core Team, 2015. R: A Language and Environment for Statistical Computing. R Foundation for Statistical Computing, Vienna. ISBN 3-900051-070. <http://www.R-project.org/>

Ritz, C., Streibig, J.C., 2005. Bioassay analysis using R. J. Stat. Softw. 12, 1-22.

Roat, T.C., Cruz-Landim, C., 2010. Mitosis and cell death in the optic lobes of workers, queens and drones of the honey bee (Apis mellifera) during metamorphosis. J. Biosci. 35, 415-425.

Roat, T.C., Carvalho, S.M., Nocelli, R.F., Silva-Zacarin, E.C.M., Palma, M.S., Malaspina, O., 2013. Effects of sublethal dose of fipronil on neuron metabolic activity of Africanized honeybees. Arch. Environ. Contam. Toxicol. 64, 456466.

Rortais, A., Arnold, G., Halm, M.-P., Touffet-Briens, F., 2005. Modes of honeybees exposure to systemic insecticides: estimated amounts of contaminated pollen and nectar consumed by different categories of bees. Apidologie 36, 71-83.

Rossi, C.A., Roat, T.C., Tavares, D.A., Cintra-Socolowski, P., Malaspina, O., 2013a. Effects of sublethal doses of imidacloprid in malpighian tubules of Africanized Apis mellifera (Hymenoptera, Apidae). Microsc. Res. Tech. 76, 552-558.

Rossi, C.A., Roat, T.C., Tavares, D.A., Cintra-Socolowski, P., Malaspina, O., 2013b. Brain morphophysiology of Africanized bee Apis mellifera exposed to sublethal doses of imidacloprid. Arch. Environ. Contam. Toxicol. 75, 234-243.

Silva-Zacarin, E.C.M., Chauzat, M.P., Zeggane, M.P.S., Drajnudel, P., Schurr, F., Faucon, J.P., Malaspina, O., Engler, J.A., 2012. Protocol for optimization of histological, histochemical and immunohistochemical analyses of larval tissues: application in histopathology of honey bee. Curr. Micro. Contri. Adv. Sci. Tech. 1, 696-703.

Stokstad, E., 2007. The case of the empty hives. Science 316, 970-972.

Thompson, H.M., 2003. Behavioural effects of pesticides in bees: their potential for use in risk assessment. Ecotoxicology 12, 317-330.

Tomizawa, M., Casida, J.E., 2003. Selective toxicity of neonicotinoids attributable to specificity of insect and mammalian nicotinic receptors. Annu. Rev. Entomol. 48, 339-364.

vanEngelsdorp, D., Meixner, M.D., 2009. A historical review of managed honey bee populations in Europe and United States and the factors that may affect them. J. Invert. Pathol. 10, 10-16.

Vidau, C., Diogon, M., Aufrauve, J., Fontbonne, R., Viguès, B., Brunet, Jean.-Luc., Texier, C., Biron, D.G., Blot, N., El Alaoui, H., Belzunces, L.P., Delbac, F., 2011. Exposure to sublethal doses of fipronil and thiacloprid highly increases mortality of honeybees previously infected by Nosema ceranae. PLoS One 6, e21550. 
Whitehorn, P.R., Connor, S.O., Wackers, F.L., Goulson, D., 2012. Neonicotinoid pesticide reduces bumble bee colony growth and queen production. Science 336, 351-352.

Williamson, S.M., Wright, G.A., 2013. Exposure to multiple cholinergic pesticides impairs olfactory learning and memory in honeybees. J. Exp. Biol. 216, 17991807.
Wu, J.J., Anelli, C.A., Sheppard, W.S., 2011. Sub-lethal effects of pesticide residues in brood comb on worker honey bee (Apis mellifera) development and longevity. Plos One 6, e14720.

Yang, E.-C., Chang, H.-C., Wu, W.-Y., Chen, Y.-W., 2012. Impaired olfactory associative behavior of honeybee workers due to contamination of imidacloprid in the larval stage. Plos One 7, e49472. 